\title{
A LENGYEL REGIONÁLIS FEJLŐDÉS A NEOKLASSZIKUS MODELL ALAPJÁN
}

\author{
(The Polish Regional Development According \\ to the Neoclassic Modell)
}

PUSZTAI JÓZSEF - AGNIESZKA SZTYRAK

\begin{abstract}
Kulcsszavak:
Lengyelország regionalis különbségek neoklasszikusmodell konvergencia divergencia

Ebben az elemzésben a neoklasszikus modell segítségével a lengyel vajdaságok meghatározott adatsorai között kerülnek feltárásra a gazdasági összefüggések, megvizsgálva, hogy ezek megegyeznek-e az empirikus tényekkel. Jelen tanulmány azzal a kérdéssel foglalkozik, hogy ha a Lengyelország regionális szerkezetében bekövetkezett változások egyensúlyi folyamatoknak tekinthetōk, milyen mértékben közelednek egymáshoz a régiók, vagyis a lengyel régiók divergálnak vagy konvergálnak? (A hipotézis maga az, hogy a lengyel régiók az elmúlt tizenöt évben divergáltak.) A kérdések megválaszolására, a regionális egyensúlyi szint meghatározására a kiterjesztett neoklasszikus növekedési modell használjuk. Vallalkozásunk nem könnyü feladat. Egyrészt azért, mert az Európai Unióhoz történt csatlakozás számos bizonytalansági tényezôt hordoz magában, így a fejlódési trendek uitemének változása várható. Másrészt további problémát jelentett számunkra, hogy a Lengyelországban lezajlott közigazgatási reform (1999) eredményeképpen a területi, statisztikai adatok bázisa nem teljesen tisztázott és megbizható. Némely esetben jellemzó a történelmi adatok teljes vagy részleges hiánya, ami jelentôs mértékben megnehezíti a fejlódési problémák makro-statisztikai megközelitését a modell szempontjából.
\end{abstract}

\section{Bevezetés}

A fejlödés és az ezzel kapcsolatos fejlettség olyan összetett fogalmak, amelyek nehezen definiálhatók, mert az értéktartalmukban nincs közmegegyezés. „Az érték meghatározottság akkor kapcsolódik egy-egy folyamat értelmezéséhez, amikor a változás fogalma helyébe a fejlődés kerül (...). Nehezíti a fogalom meghatározását, hogy jellemzően nem egy könnyen mérhetö mennyiségi, hanem soktényezös minöségi fogalomról van szó." (Nemes Nagy 1998, 236)

A fejlődés két elemböl áll, a növekedésböl és a struktúraváltozásból, amelyek együtt új jelenséget hoznak létre. A két fogalom eltérö, a növekedés mennyiségi változást jelöl, a fejlődés pedig egy magasabb randú állapot felé tö ‘énő elmozdulásra utal. A gazdaság növekedése többnyire a gazdaság fejlödését, a térség potenciális kibocsátásának a bövülését szolgálja, de vannak kedvezőtlen hatásai is.

A gazdasági növekedés hatása a területi fejlettségre kettős lehet. Egyik a konvergencia, ami azt jelenti, hogy az általános gazdasági növekedés új eröforrások bevonását igényli, a szétterülő gazdasági növekedés hatására egyre fejlettebb környezet jön létre. (Horváth-Rechnitzer 2000) Az optimális gazdasági növekedés velejárója a regionális különbségek csökkenése. (Ellentétes esetben a divergencia jelensége 
Pusztai József - Agnieszka Sztyrak : A lengyel regionális fejlődés a neoklasszikus modell alapján.

Tér és Társadalom 19. évf. 2005/3-4. 205-212. p.

TÉT XIX. évf. 2005 -3-4

lép fel.) Myrdal elmélete szerint a magára hagyott gazdaságban nőnek a fejlettségi különbségek, és az a tendencia tapasztalható az egy före jutó jövedelem statisztikák alapján, hogy a fajlagos jövedelem közötti különbség nő. Elmélete szerint a gazdasági növekedés hatására a régiók divergálnak. Amiből a Máté-effektus (Biblia) következik: a gazdagabbak még gazdagabbakká lesznek, a szegények pedig még szegényebbekké. Szerinte a gazdasági növekedés fejlettségre gyakorolt hatása annak a függvényében alakul ki, hogy a gazdaság milyen innovációs képességgel rendelkezik (Hajdú 2005).

Egy-egy régió gazdasága sajátos törvényszerüséggel bír. A regionális fejlődésnek alapvetö egyensúlyi feltételei vannak. Amennyiben egy nemzetgazdaságban a kapcsolódó térségek között jelentős gazdasági diszharmónia van, akkor a különböző régiók dezintegrálódhatnak, és ez még nagyobb fejlődésbeli különbségekhez vezet. A régiók közötti különbségek egyrészt az eltérö társadalmi, gazdasági adottságokra, valamint ezek kihasználtsági fokára, illetve nemzetgazdasági szinten az egyes régiók közötti együttmüködés zavaraira vezethetök vissza (természetesen külföld felé zárt gazdaság manapság nem létezik). Az egyedi belső adottságok és lehetőségek, valamint az ebböl származó elönyök/hátrányok nem függnek külső feltételektől. Viszont a külső kapcsolatok a régió fejlődésére jelentösen hatnak, differenciáló vagy nivelláló hatásuk van (Horváth-Rechnitzer 2000).

Az egyenlőtlenség (közgazdasági iskolánként sokszor merőben eltérően) több tényezőre vezethető vissza. A klasszikus felfogás szerint különös jelentősége van a természeti, földrajzi adottságoknak.

A regionális szerzők többsége a múködö tőke jelentőségét emeli ki. Minél nagyobb a tőke koncentrációs képessége, annál nagyobb lehetőségei vannak a gazdasági fejlődésnek. (A tóke hiánya rendkívül negatívan hat a gazdasági szerkezetre, különösen az infrastruktúra fejlesztése területén). További differenciáló tényezöje a régiónak a munkamegosztásban elfoglalt helye, relatív zártsága. Az áruszerkezet aszimmetriája a térség sebezhetőségét, strukturális hátrányait fejezi ki (ez érvényesül pl. olyan monokulturális régió esetében, amely a következö jellemzőkkel bír: a termékei alacsony diverzifikáltságúak és feldolgozottsági fokúak, ezért a régió szinte teljes mértékben magas hozzáadott értékủ importra szorul, azonban ezt nem ellentételezi magas hozzáadott értékü exporttal). Végül, de nem utolsó sorban megemlítjük a belső piac nagyságát, keresletszerkezetét és a fogyasztói preferenciákat, mint szintén fontos magyarázó faktorokat. Tehát, mint a teljesség igénye nélküli felsorolásból is látható, számos tényező gyakorol befolyást az egyes régiók fejlödésére, amely magyarázatok mindegyike egy-egy jelentős közgazdasági iskola instrumentumait használja érvelésében. Talán ez a kutatás annyiban eltérö, hogy a neoklasszikus iskolán túl számos primer kutatást (pl. interjúk), illetve rendkívül böséges szekunder adathalmazt vizsgál. 
Pusztai József - Agnieszka Sztyrak : A lengyel regionális fejlódés a neoklasszikus modell alapján. Tér és Társadalom 19. évf. 2005/3-4. 205-212. p.

TÉT XIX. évf. 2005 3-4

Kitekintö

207

\section{Konvergencia fogalma}

A neoklasszikus modell fö tulajdonsága, hogy lehetővé teszi a feltételes konvergencia ( $\sigma$-konvergencia) elörejelzését. Ez akkor használható, ha a növekedési ráta pozitív összefüggésben van a GDP-vel és a saját egyensúlyi állapot (1) közötti távolsággal. (A feltételes konvergencia nem azonos az abszolút konvergenciával.) Az alapkoncepció szerint a kevésbé fejlett gazdaságok gyorsabban növekednek, mint a fejlett gazdaságok, ebböl következik, hogy az idő folyamán a két fejlettségi szint kiegyenlítődik. A két koncepció azonos, ha a gazdaságok ugyanahhoz a steadyponthoz konvergálnak. Továbbá ebben az esetben a neoklasszikus növekedési modell prognosztizálja az abszolút konvergenciát ( $\beta$ - konvergencia) is (kevésbé fejlett gazdaságok gyorsabban fejlödnek a fejlett gazdaságoknál). Így a konvergencia létezése igazolásának egyik ellenőrzési módja megvizsgálni, vajon a gazdaságok, amelyekre hasonló preferenciák és technológiák a jellemzők, közelítenek-e ugyanazon egyensúlyi állapothoz (abszolút értelemben) (Barro-Sala-I-Martin 2004).

Ebben az elemzésben teszteljük a konvergenciát, amelyet a neoklasszikus modell segítségével alkalmazunk az ország régióinak vizsgálatára. Bár léteznek jelentős különbségek a technológiában, a szokásokban, a fejlettségben és intézményekben egy országon belül is, ezek az eltérések átlagosan kisebbnek látszanak az országok közötti különbségeknél (Aghion-Caroll-Garcia-Penelosa 1999) (persze ez alól kivételek a kontinensnyi országok, illetve ennek ellenkezőjeként az Unión belüli relatíve kicsi országok közötti eltérés ennek ellentmondhat). A vállalatoknak és a háztartásoknak (ugyanazon országban) különböző régiókban ugyanaz (vagy hasonló) a technológiákhoz (pl. know-how) való hozzáférésük, a háztartások nagyjából hasonló preferenciákkal, szokásokkal, kultúrával stb. rendelkeznek. Továbbá ezeknek a régióknak közös a központi kormányuk, jegybankjuk, monetáris politikájuk stb., valamint hasonló intézményi és jogi rendszerrel rendelkeznek. Ez a relatív homogenitás azt jelenti, hogy az egy országon belüli régiók nagyobb valószínủséggel közelítenek egy egyensúlyi ponthoz. Ezért az abszolút konvergencia fogalma inkább használható régiók között, mint a különböző országok között (Barro-Sala-I-Martin 1992).

Elismerem azonban, hogy vitatható, hogy a régiók használata (országok helyett behelyettesítve) a konvergencia modell teszteléséhez teljesen helyénvaló-e, mert az inputok valóban mobilabbak régiók között, mint országok között. Jogi, kulturális, nyelvi és intézményi gátak kevésbé vagy egyáltalán nem jelennek meg egy adott ország régiói között, ellentétben az országok közötti összehasonlítással (azonban pl. az EU is egyre inkább ellentmondani látszik ennek, de a WTO törekvése is hasonló). Ezért a zárt gazdaság feltételezése - a neoklasszikus modell standard kikötéseként valószínüleg sérti a regionális adatforrások és eredmények teljes megbízhatóságát, azonban megítélésünk szerint domináns tendenciák kirajzolására alkalmas.

Mindemellett, a gazdaságok dinamikus tulajdonságai, amelyek már nyitottak a tókemozgásokra, összehasonlítóak a zárt gazdaságokéival, ha a tőke, amely magába foglalja a humán tökét, nem mobilis, vagy nem használható fel járulékként interregionális, valamint nemzetközi tranzakciókhoz. A konvergencia sebessége 
Pusztai József - Agnieszka Sztyrak : A lengyel regionális fejlódés a neoklasszikus modell alapján.

Tér és Társadalom 19. évf. 2005/3-4. 205-212. p.

növelhetö a tökemobilitás létezése miatt. Másik eredmény, hogy a technológia, csökkenő tőkemegtérülés nélkül implikálja a nulla konvergenciát, függetlenül attól, hogy a gazdaság nyitott vagy zárt.

Emellett meg kell említenem, hogy a migráció fokozza a konvergencia folyamatát. Ez lehetôvé teszi a konvergencia sebességének befolyásolását.

Ebböl azt a következtetést vonhatjuk le, hogy annak ellenére, hogy a régiók egy országon belül relatíve nyitottak a humán- és tökemozgásokra, a neoklasszikus modell alkalmas keretet ad az empirikus vizsgálat számára.

\section{Abszolút $\beta$-konvergencia a lengyel régiókon keresztül}

A lengyel régiók adatsorait használom fel (2) az abszolút konvergencia ( $\beta$ ) sebességének a megbecsüléséhez. Ebben a munkában (terjedelmi korlátok miatt) eltekintek a konvergencia részletesebb elméleti leírásától (Barro-Sala-I-Martin 2004).

Feltételezzük, hogy ebben a pillanatban a megfigyelésünk száma csak a tidőpontra vonatkozik, 0 és T. A neoklasszikus modell alapján az következik, hogy az átlagos egy före jutó növekedési ráta i gazdaság számára 0 , T idöintervallumban a következő:

1. $(1 / T) \cdot \log \left(y_{\mathrm{iT}} / \mathrm{y}_{\mathrm{i} 0}\right)=\mathrm{x}-\left[\left(1-\mathrm{e}^{-\beta \mathrm{T}}\right) / \mathrm{T}\right] \cdot \log \left(\mathrm{y}_{\mathrm{i} 0}\right)+\left[\left(1-\mathrm{e}^{-\beta \mathrm{T}}\right) / \mathrm{T}\right] \cdot \log \left(\hat{\mathrm{y}}_{\mathrm{i}}{ }^{*}\right)+\mathrm{u}_{\mathrm{i} 0 \mathrm{~T}}$

A $u_{i 0, T}$ kifejezés a hiba $u_{i t}$ effektusát jelenti, $0, T$ idöszakban: $\left(\hat{y}_{\mathrm{i}}{ }^{*}\right.$ ) a jövedelem egyensúlyi szintje: $\mathrm{x}$ a technológiai növekedés rátája, amelyröl feltételezzük, hogy ugyanilyen mértékủ minden gazdaságban.

A kezdeti jövedelem koefficiense a (1-e $\left.\mathrm{e}^{-\beta T}\right) / T$, amely idővel csökken az időperiódus T csökkenésével, adott $\beta$-val. Azaz ha lineáris összefüggést feltételezünk a növekedési ráta és a kezdeti jövedelem között, feltételezhetö, hogy a koefficiens csökkenni fog az időintervallum növekedésével, amelyben a növekedési rátát átlagoljuk.

A 1-es egyenletben a $\left[\left(1-\mathrm{e}^{-\beta \mathrm{T}}\right) / \mathrm{T}\right] \cdot \log \left(\mathrm{y}_{\mathrm{i}}{ }^{*}\right)$ kifejezés a magyarázó változó. Azt jelenti, hogy i gazdaságnak a növekedési rátája yi0 kezdeti jövedelemtỏl függ, de az egyensúlyi jövedelem szintjétől is függ, ezért használjuk inkább a feltételes, mint az abszolút konvergenciát. A gazdaság növekedési rátája negatív összefüggésben van a kezdeti jövedelemmel.

Azon célból, hogy jobban tudjunk dolgozni a regionális adatokkal, a többváltozós egyenlet helyett megbecsüljük az egyváltozós regressziót.

2. $(1 / T) \cdot \log \left(y_{\mathrm{iT}} / \mathrm{y}_{\mathrm{i} 0}\right)=\mathrm{a}-\left[\left(1-\mathrm{e}^{-\beta \mathrm{T}}\right) / \mathrm{T}\right] \log \left(\mathrm{y}_{\mathrm{i} 0}\right)+\mathrm{w}_{\mathrm{i} 0, \mathrm{~T}}$

A 2. egyenletben $\left.\left[\left(1-\mathrm{e}^{-\beta \mathrm{T}}\right) / \mathrm{T}\right] \log \left(\hat{\mathrm{y}}_{\mathrm{i}}{ }^{*}\right)\right]$ kifejezés már nem a magyarázó változó. Ha a kifejezés, amely a gazdaság kezdeti jövedelmének a koefficiense a 2-es egyenletben negatív, akkor feltételezhetjük, hogy a szegényebb gazdaságok gyorsabban növekednek, mint a gazdagabbak, ami az abszolút konvergencia feltétele.

Az alábbi ábra megmutatja az összefüggést az átlagos éves növekedési ráták és az 1 före jutó GDP között a 16 lengyel vajdaság adatsoraiban. 
Pusztai József - Agnieszka Sztyrak : A lengyel regionális fejlődés a neoklasszikus modell alapján.

Tér és Társadalom 19. évf. 2005/3-4. 205-212. p.

TÉT XIX. évf. 2005 -3-4

Kitekintö

209

\section{1. ÁBRA}

Az 1995-2002 közötti átlagos növekedési ráták és

1 före jutó GDP-re vonatkozó regressziója

(Regression of the Average Growth Rate between 1995-2000 and of the GDP per Capita)

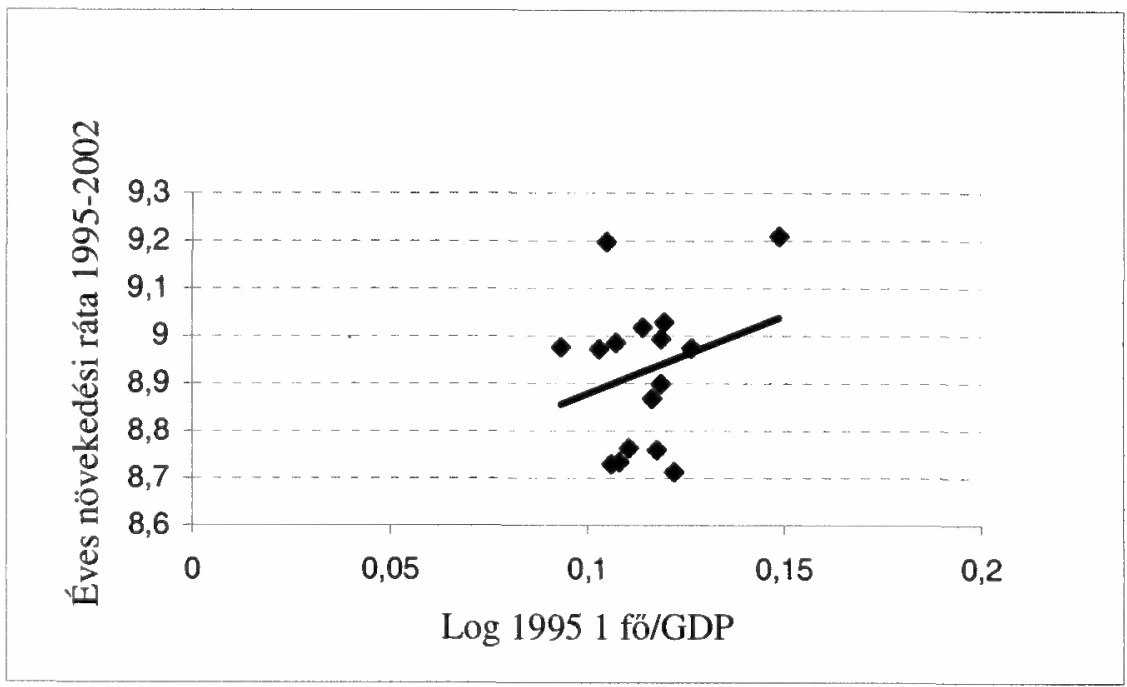

Forrás: Saját szerkesztés (Central Statistical Office 2002, 2003).

$\mathrm{Az}$ ábrából is sejthetjük, hogy a létező òsszefüggés inkább a divergenciát, mint a konvergenciát bizonyítja, azaz a különbségek a lengyel régiók között nőnek.

\section{TÁBLÁZAT \\ Alapinformációk \\ (Basic Information)}

\begin{tabular}{ccccc}
\hline \multirow{2}{*}{ IDŐSZAK } & \multicolumn{2}{c}{ ALAPEGYENLET } & \multicolumn{2}{c}{ ALAPEGYENLET+STRUKT. PARAM. } \\
& $\beta$ & {$[R 2]$} & $B$ & {$[R 2]$} \\
\hline \multirow{2}{*}{$1995-2002$} & -0.01919 & $6.70 \%$ & -0.0345 & $27.70 \%$ \\
& $(0.0204)$ & $(0.01236)$ & $(0.03430)$ & $(0.01228)$ \\
\hline
\end{tabular}

Forrás: Saját számítás (Central Statistical Office 2002, 2003).

Megjegyzés: A regresszió felhasználja a nem lineáris legkisebb négyzetek módszerét az egyenletből a fenti paraméterek megbecsüléséhez a következő formulából:

$(1 / T) \cdot \log \left(y_{i t} / y_{i, t-T}\right)=a-\left[\left(1-e^{-\beta T}\right) / T\right] \cdot \log \left(y_{i, t-T}+\right.$ más paraméterek

ahol, $\log \left(\mathrm{y}_{\mathrm{T}-1}\right)$ az 1 főre jutó GDP i állapotban az időszak kezdetén, elosztva az átfogó CPI-vel, T a periódus hosszát jelenti. A minta, amely 1995-ben kezdődik, 16 megfigyelésből áll. Minden oszlop tartalmazza $\beta$ becslését, ennek a standard hibáját, a regressziónak az R2-es standard hibáját. A likehood-arány statisztikája a koefficiensek egyenlöségére vonatkozik, a kezdeti jövedelem logaritmusára az adott időszakban. 
Pusztai József - Agnieszka Sztyrak : A lengyel regionális fejlódés a neoklasszikus modell alapján.

Tér és Társadalom 19. évf. 2005/3-4. 205-212. p.

Az elsö oszlopban megnézhetjük az egyenletet csak egy magyarázó változóval, az 1 före jutó GDP (az időszak kezdetén) logaritmusát. A második oszlopban megtalálhatók a koefficiensek, amelyeket megbecsültünk az egyenletböl, amely tartalmazza a strukturális paramétereket.

Az első megbecsült $\beta$ koefficiens negatív (-0.01919), ami bizonyítja a konvergencia hiányát. A negatív összefüggés arra utal, hogy a szegény régiók lassabban növekednek, mint a gazdagabb régiók. A divergencia sebessége 1,9\%, amely a régiók lassú, de széttartó irányú fejlödésére utal.

Az aggregált strukturális sokkok különböző súllyal érintették a vizsgált vajdaságokat, ezért magyarázattal szolgálnak a koefficiens instabilitására (Barro-Sala-IMartin 2004). Ezért a táblázat második oszlopában hozzáadjuk a pótlólagos változót a regresszióhoz, amelynek célja az aggregált strukturális sokkok konstansként tartása. A változót $\left(S_{\mathrm{it}}\right)$ a következő egyenlet adja:

$$
\text { 3. } \mathrm{S}_{\mathrm{it}}{ }_{\mathrm{j}=1}^{2}=\sum_{\mathrm{j}} \mathrm{w}_{\mathrm{ij}, \mathrm{t}, \mathrm{T}} \cdot\left[\log \left(\mathrm{y}_{\mathrm{jt}} / \mathrm{y}_{\mathrm{j}, \mathrm{t}-\mathrm{T}}\right) / \mathrm{T}\right] \text {, }
$$

ahol a $\mathrm{w}_{\mathrm{ij}, \mathrm{t}-\mathrm{T}} \mathrm{j}$ a szektor súlya a vajdaságban, i-edik jövedelemben, $\mathrm{t}-\mathrm{T}$ időpontban, $\mathrm{y}_{\mathrm{jt}}$ a nemzeti átlagjövedelem dolgozónként, $\mathrm{j}$ szektorban, $\mathrm{t}$ időpontban. Ebben a dolgozatban csak két szektort veszünk figyelembe, a mezőgazdaságot (halászattal, erdészettel, valamint vadászattal együtt), és az ipart, amelynek domináns szerepe van a GDP termelésben.

A strukturális változó megmutatja, hogy mennyire fog nöni a régió, amikor mindegyik szektor fejlödni fog a nemzeti jövedelem átlagos (GDP) növekedési rátája mértékében. Így például, ha feltételezzük, hogy i-edik régió fö jellemzője a személyautó-gyártás, és hogy az aggregált személyautó-gyártás szektora nem nőtt a $\mathrm{T}$, $\mathrm{t}$ időszakon belül, akkor az $\mathrm{S}_{\mathrm{it}}$ kicsi értéke azt sugallja, hogy a szektor nem nőhet gyorsan, mert a személyautó-gyártás recessziótól szenved.

A változó függ az időszakos nemzeti átlagok növekedési rátáitól és a régió részesedésétől az adott szektorban. Ezért is lehet a változót exogénként kezelni az i régió növekedésében.

Az esetünkben megfigyelhetjük, hogy a strukturális változók bevonása nem változtatja meg a régiók fejlődési irányát, sőt jelentős mértékben felgyorsítja $(\beta=-0.0345)$ a széttartó fejlődési irányt. Szintén észrevehetjük, hogy a modell magyarázó ereje szignifikánsan nött.

\section{Feltételes $\sigma$-konvergencia}

Az alábbi táblázat megmutatja az egy fỏre jutó GDP logaritmusának standard szórását 1995 és 2002 között 16 vajdaságban (Central Statistical Office 2003). 
Pusztai József - Agnieszka Sztyrak : A lengyel regionális fejlődés a neoklasszikus modell alapján.

Tér és Társadalom 19. évf. 2005/3-4. 205-212. p.

TÉT XIX. évf. 2005 - 3-4

Kitekintö

211

\section{2. ÁBRA}

Egy forre jutó GDP logaritmusának standard szórása, 1995-2002

(Standard Dispersion of the Logarithm of GDP per Capita, 1995-2002)

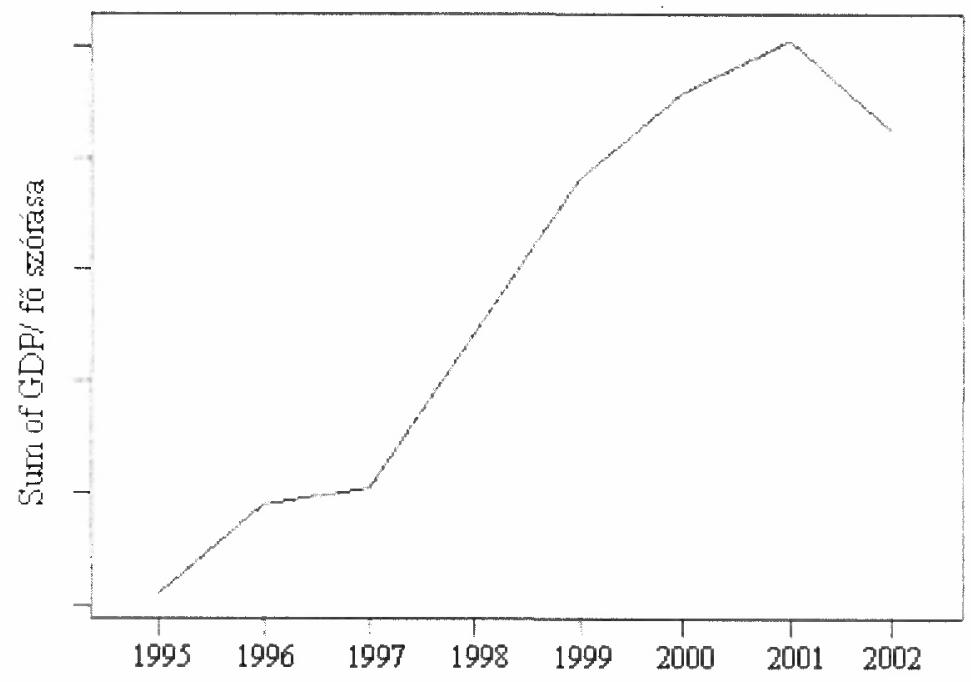

Forrás: Saját szerkesztés (Central Statistical Office 2002, 2003).

A táblázatból láthatjuk, hogy a különbségek folyamatosan nőttek 0.1564-tól (1995-ben) 0.2054-ig (2001-ben), amikor is elérték a csúcsot. 2002-ben a $\sigma$ némileg csökkent, 0.1975 értékig.

\section{Konklúzió}

Az ebben az elemzésben bemutatott vizsgálatok azt bizonyítják, hogy a lengyel régiók divergálnak, évente $\mathrm{kb}$. $2 \%$-os sebességgel, vagyis a szegényebb régiók lassabban fejlödnek a gazdagabb régióknál.

A neoklasszikus növekedési modell alkalmazása megmutatja a konvergencia hiányát a lengyel régiók fejlödésében. Ez a tény indirekt módon bizonyítja a divergencia létezését, vagyis a vajdaságok széttartó irányú fejlődését.

\section{Jegyzetek}

${ }^{1}$ Az egyensúlyi állapot a nemzetközi irodalomban használt „steady state” kifejezésnek felel meg, ezeket kölcsönösen felcserélve használjuk ebben a fejezetben.

${ }^{2}$ A vizsgálatot a lengyel Central Statistical Office, a lengyel Nemzeti Bank, illetve a saját számításaink alapján végeztủk a Minitab statisztikai program segítségével. 
Pusztai József - Agnieszka Sztyrak : A lengyel regionális fejlődés a neoklasszikus modell alapján.

Tér és Társadalom 19. évf. 2005/3-4. 205-212. p.

\section{Irodalom}

Aghion, Ph.-Caroll, E.-Garcia-Penelosa, C. (1999) Inequality and Economic Growth: The Perspective of the New Growth Theories - Journal of Economic Literature. 1. 1615-1661. o.

Barro, J.R.-Sala-I-Martin, X.(1992) Regional Growth and Migration: Japan-US Comparison. Working Paper No 4038; National Bureau of Economic Research.

Barro, J.R.-Sala-I-Martin, X. (2004) Economic Growth (Second Edition). Massachusetts Institute of Technology, Massachusetts.

Nemes Nagy J. (1998) A tér a társadalomkutatásban: Bevezetés a regionális tudományba. Hilscher Rezsö Szociálpolitikai Egyesület, Budapest.

Horvăth Gy.-Rechnitzer J. (szerk.) (2000) Magyarország terïleti szerkezete és folyamatai az ezredfordulón. MTA RKK, Pécs.

Central Statistical Office (2002) Concise Statistical Yearbook of Poland 2001. Year XLIV. Warsaw.

Central Statistical Office (2003) Statistical Yearbook of the Regions-Poland 2002. Warsaw.

Hajdú Z. (2005) Magyarország közigazgatási földrajza. Dialóg Campus, Budapest.

\section{THE POLISH REGIONAL DEVELOPMENT ACCORDING TO THE NEOCLASSIC MODELL}

\section{JÓZSEF PUSZTAI - SZTYRAK AGNIESZKA}

The global economy is driven by three interlocked processes: globalization, competition and innovation. None of them would be possible had not the other two existed.

During the last 10-15 years a growing territorial polarization is observed. The growth of the territorial differences can be explained on the grounds of the exogenous and the endogenous factors of development. These disparities are both the products of more distant history, and the results of recent processes.

In the present essay the development of the Polish regions is discussed more than 10 years after the political system transformation. The growth rates of recent years and the traditional industrial structures do not support the thesis of quick convergence. However, the main regions and the Westem border territories are developing dynamically. Consequently, a relatively durable gap can be expected, as well as increased regional differentiation within the country.

In this essay the divergence amongst growth of Polish regions has been proved. The method of the verification was settled by the neoclassical growing modell. 